\title{
Die rol van die natuurwetenskaplike in samelewingsontwikkeling - uitdagings vir Suid-Afrika*
}

\author{
P. van Eldik \\ Technikon Pretoria, Privaat sak X680, Pretoria, ()(0)1
}

\section{UITTREKSEL}

Die onteding van 'n aamal internasionale en masionale tendense en ervenings bevestig die noodsakklikheid vir die herposisionering,

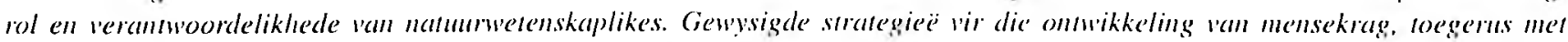
wetenskaplike en tegnologiese kandigheid en vaardighede. bied besondere airdagings. Daarmee saam is die byadraes ran natumwetenskaplikes, deur navorsing en onwikkeling, tor mune kennis, asook die torpassing en benuming van kennis in nuwe prosesse, produkle en tegnologie-oordrag van kardinale belang.

\begin{abstract}
The role of scientists in societal development - challenges for South Africa

International and local trends and experiences confirm the importance of reassessing the role and responsibilities of scientists in South Africa. Revised strategies for human resource developmem, equipped with scientific and lechnological expertise and skills, offer tremendous challenges to scientists and the higher education system of the coumty: Simulameous/y the contributions of scientists, through their involvement in research and development, to new knowledge as well as the application and atilisation of knowledge in new processes, products and techmology aransfer; is of rital importance for the economic development of South Africa.
\end{abstract}

Binne 'n snel veranderende omgewing op nasionale en mternasionale vlak bestaan daar vir Suid-Afrika en sy mense besondere uitdagings en geleenthede. Die tyd is oorryp om op pro-iktiewe wyse daadwerklik skoucr aan die wiel te sit om hicrdic uitdagings en gelecnthede aan te gryp en te benut. Maar daarvoor is 'n herbesinning oor ons betrokkenheid die afgelope aantal jare noodsalaklik - die tradisionele wyse van ons betrokkenheid en rol in samelewingsontwikkeling is net nic meer goed genoeg nic

'n Dringende pleidooi word gelewer vir die herposisionering van natuurwetenskaplikes se rol en verantwoordelikhede in samelewingsontwikkeling.

Herposisionering is absolut noodsaaklik om alan die eise en uitdagings wat gestel word, te kan voldoen. llierdie standpunt word toegelig deur die bespreking van 'n aantal internasionale en nasionale tendense en ervarings, waarna die fokus sterk op die rol van die natuurwetenskaplike toegespits word. Die referail is hoolsaaklik beperk tot die rol van die natuurwetenskaplike, walaronder die wiskundige, fisiese, chemiese, aardkundige, landboukundige en biologiese wetenskappe ingesluil word. Dic standpunte wat gestel word, sou ook op ander dissiplines van toepassing kon wees.

\section{DIE WêREI.D WAARIN ONS I.EWE}

Suid-Afrika het begin met 'n massiewe poging tot heropbou en ontwikkeling om daardeur te verseker dat dic land in hoogste rat van ekonomiese vernuwing en groei kan beweeg, wat weer op sy beurt kan lei tot 'n rooskleurige toekoms vir al sy inwoners.

Die volgende drie kernaspekte van hierdic strategic is welbekend:

* Voorsiening van basiese behoeftes

Dit sluit in die verskalfing van doelmatige behuising, water- voorsiening, elektrisiteitsvoorsiening, geskikte sanitasiestelsels, inlrastruktuurvoorsiening waaronder paaic, vervoerstelsels, winkelsentrums, sckuriteit, asook dic daarstelling van 'n primêre en sckondêre skoolstelsel en geskikte gesondheidsorgstelsels.

\section{* Ekonomiese ontwikkeling}

Daar bestaan twee sterk fokusse: alan die een kant die noodsaaklikheid van strecks-en regionale ontwikkeling van handel en nywerheid om werkskepping te verseker en daardeur die huidige werkloosheidskrisis die hool te bied. Datulecnoor ook die noodsalak likheid om die internasionale mededingendheid van Suid-Aliika te bevorder met wêreldklasprodukte, uitvoere, internasionale strategiese alliansies en voorpuntbydraes op tegnologiese terreine.

\section{* Menslike hulpbrononmikkeling}

Geen ontwikkeling is moonl lik sonder 'n goed opgeleide werksmag van kundige persone loegerus met vaardighede wal toepaslik is vir die ontwikkelingslase waarin dic land verkeer nie. Die bemagliging van mense deur onderwys en opleiding bly steeds die grootste vitdaging waarvoor Suid-Afrika staan.

'n Internasionale perspekticl hicrop is ook van belang. In 'n onlangse publikasie getitel The Taiw'an Experience: Implications for South Africa' 'word die stralegiese belang van opleiding van mense, en in besonder opleiding in die natuurwetenskappe en tegnologieë vir verdere nywerheidsont wikkeling, beklemtoon.

Terselidertyd moel dil weereens onder die aandag gebring word dat Suid-Alrika nog steeds laag op die ranglys vir mededingendheid lê. Die jongste verslag van die Wêreld Ekonomiese Forum wat in Mci 1997 uitgereik is, plaas Suid-Afrika in dic 44 sle algelicle plek uit 5.3 lande. Met betrekking to die ontwikkeling van menslike hulpbronne wat kan bydra tot 'n 
mededingende ekonomie beklee Suid-A rrika, soos die afgelope vier jaar, steeds die laaste posisic.

As deel van die strategie van die Suid-Afrikaanse regering vir heropbou en ontwikkeling is daar gedurende die afgelope drie jaar 'n aantal beleidsdokumente ontwikkel wat tot nuwe wetgewing aanleiding gegee het. In hierdie verband is dic volgende veral van belang:

- Witskrif oor Wetenskap en Tegnologic

- Witskrif oor Klcinsakc-ontwikkeling (KMMO's)

- Makro-ekonomiesc Strategic (GEAR)

- Konsep-Witskrif oor Hoër Onderwys

Die volgende aspekte van hierdic beleidsdokumente wat dirck op die tema betrekking hel, word beklemtoon:

* Dic ontwikkeling van 'n Nasionale Stelsel van Innovasie om die bereiking van nasionale doel witte te verseker deur die kreatiewe benutling van dic uitsette van die weicnskaps- $\mathrm{en}$ tegnologiestelsel met betrekking tot nuwe kennis en nuwe tegnologie. Die kennis, tegnologie, produkte en prosesse geproduseer, moet omgeskakel word in verhoogde welvaart en 'n beter kwaliteit lewe vir almal in die gemeenskap.

* Dic ontwikkeling van Klein, Medium en Mikro-ondernemings (KMMO's) in die vervaardiging- en dienstesektore word as 'n hoë prioriteil geidentifiseer. ${ }^{3}$ Hiervoor is daadwerklike ondersteuning in tegnologie-ontwikkeling, innovasic en tegnologie-oordrag deur natuurwetenskaplikes, ingenieurs en tegnoloë van die uiterste belang.

* 'n Makro-ckonomiese strategie vir Suid-Afrika waarin die rol van die handel en nywerheid, die arbeidsmag, die regering en die breë gemeenskap in perspektief geplaas word en waarin die beginsel van samewerking in dic identifisering en ontwikkeling van bepaalde nywerheidsektore sterk ondersteun word. Dit is in ooreenstemming met die ervaring van Taiwan waarna reeds verwys is. Dit is interessant om daarop te wys dat die huidige studic wat deur die Departement van Kuns, Kultuur, Weienskap en Tegnologic onderneem word insake 'n nasionale navorsings- en tegnologievooruitskouing ${ }^{+}$dic volgende twaalf sektore geidentiliseer het warop gekonsentreer sal word:

- Landbou en prosessering

- Gesondheid

- Omgewingsbestuur

- Vervaardiging

- Besigheids- en finansiële diensle - Mynwese

- Biodiversitcit

- Veiligheid en

- Inligtingsgemeenskap

sekuriteit

- Energic

- Toerisme

- Jeug

* Dic Konsep-Witskril oor Hoër Onderwys ${ }^{5}$ beklemtoon:

- die mobilisering van die talente en potensiaal van mense;

- die ontwikkeling deur hoër onderwys van beroepsmense en kenniswerkers mel vaardighede om die land se ondernemings, dienste en infrastruktuur te versterk. In besonder word verwys na dic tekorte van hoogs opgeleide persone in die natuurwelenskappe, ingenieurswese en tegnologie;

- die feit dat nasionale groei en mededingendheid afhanklik is van 'n industriële ontplooiing gekarakteriseer deur voortdurende tegnologiese verbetering en innovasie. gelei deur 'n goed georganiseerde, akticwe navorsings- en ontwikkelingstelsel;

- die regstelling en kapasiteitsbou met betrekking tot die wanbalanse van die verlede en voorheen benadeelde gemecuskappe

Is hierdie voorafgalande inligting vir natuurwetenskaplikes 'n bedreiging of sien hulle dit as 'n uitdaging? Is natuurwetenskaplikes in hoër onderwys en wetenskapsrade gereed hiervoor?

Bernic Fanarolf" is van mening dat natuurwetenskaplikes en ingenieurs 'n kernrol hierin het mits hulle bereid is om met innovasic en kreatiwiteit toe te tree. Hy gaan voort:

Our programmes of suppont for tertiary education and lor human capital must recognise the need to retain very capable and skilled researchers. However, that does not mean that people should be free to continue business as belore. We cannot assume that because we have been doing things in the past, we should continue doing those things.

En dan die belangrike vraag:

How can we develop and train high level science and technology expertise, while at the same time improving our efficiency and re-orientating our work towards those areas which are in accordance with the goals that we have set for ourselves as a nation?

Ahmed Bawa ${ }^{7}$ ondersteun hierdie standpunt en beklemtoon dat wetenskaplikes en ingenieurs sal moet verseker dat menslike hulpbronne gelewer word wat geskik sal wees vir die eise van heropbou, ontwikkeling en internasionale mededingendheid.

Hicrdic uitdagings word voorgehou te midde van ernstige finansiële beperkings, misdaald, werkloosheid en ander negatiewe tendense in ons land. Dairin is Suid-Alrika ook nic uniek nic. 'n Onlangse UNESCO-verslag ${ }^{*}$ oor verandering en ontwikkeling in hoër onderwys toon duidelik drie wêreldwye tendense:

* massa toestroming na hoër onderwys;

* wysiging/diversifikasic van strukture en programme;

* linansiële beperkings.

Die verslag beval ook die volgende waardevolle wenk:

The responses ol higher education to a changing world should be guided by three watchwords which determine its local, national and international standing and functioning:

- relevance

- quality

- internationalization

\section{DIE ROL VAN NATUURWETENSKAPLIKES IN MENSLIKE HULPIBRONONTWIKKELING}

Een van dic kernaspekte wat in samelewingsont wikkeling na vore trec, is die ontwikkeling van mense. In die vorige paragrawe is reeds verskeic kere hierna verwys asook na bepaalde cienskappe en valardighede waarmee mense toegerus moet wees.

Dit is duidelik dat die land natuurwetenskaplikes nodig het met hoëvlak-deskundigheid en -vaardighede wat tot op die voorpunt van die vakdissipline kan beweeg. Terselfdertyd bepleit die UNESCO-verslag ${ }^{*}$ die bevordering van interdissiplinêre en multidissiplinêre benaderings en metodes in onderwys en opleiding (en in navorsing) gekoppel aan die nasionale prioriteite van 'n land of streek. Volgens dié verslag is dit hierdie persone waarop dic suksesvolle skepping van $k$ waliteit werksgelcenthede berus. 
Dic verslag meld vervolgens:

Merely increasing curriculum content and students' work-load cannot be a viable solution. Preference should be given to subjects which develop students' intellectual capacity and allow them to deal judiciously with technological, economic and cultural change and diversity, equip) them with gualities such as initiative, an entreprencurial altitude and adaptability and allow them to function with grealler contidence in a modcrn environment.

Die onderstaande T-model is 'n poging om hierdie valardighede waarmee natuurwetenskaplikes toegerus moet wees, to illustreer

\begin{tabular}{|c|c|}
\hline & $\begin{array}{ll}* & \text { Kommunikasie } \\
* & \text { Innovasie en kreatiwiteit } \\
* & \text { Entrepreneurskap } \\
* & \text { Multidissiplinêre } \\
& \text { koöperatiewe vaardighede } \\
* & \text { Sosiale, gemeenskaps- en } \\
& \text { ekonomiese bewustheid }\end{array}$ \\
\hline $\begin{array}{l}\text { Wetenskaplike en } \\
\text { tegnoiogiese kundigheid }\end{array}$ & \\
\hline Figutur I: T-model. & \\
\hline
\end{tabular}

Dit is ' $n$ hoofletter $\mathrm{T}$ waarvan die vertikale en horisontale balkies ewe lank is. Die vertikale balk dui die wetenskaplike en tegnologiese kundigheid aan. Die horisontale balk gee 'n aanduiding van ander noodsaaklike vaardighede en kundighede wat nodig is, en die uitdaging is dat natuurwetenskaplikes op 'n gëmtegreerde wyse met beide komponente vertroud moet wees.

Dènis van Rensburg "lewer' 'n pleidooi dat Teclunikon Pretoria veel meer aandag en lyd in sy sillabusse en onderrig aan alle aspekte en lasette van entrepreneuriese onderwys moet skenk. Die ontwikkeling van 'n reeks persoonlike vaardighede beloort volgens hom aangemoedig te word, wat insluit kreatiwiteit, spanwerk, leicrskap, onderhandeling en oortuiging, problecmoplossing, sosiale, gemeenskaps-en ekonomiese bewustheid, prestasicmotivering, kommunikasie en inligtingstegnologie.

Die T-model word ook ondersteun deur Gary Tooker, ${ }^{10}$ die Hoof Uitvocrende Beampte van Motorola in die VSA, wanneer hy skryl:

We find that today's graduates have impressive technical skills, and for that we are grateful. But what we need are graduates with interpersonal and team-building skills as well. We need people who have high expectations of quality and product leadership. We need people who communicate well, both orally and in writing. We need people who respect llie differences in other cultures and can harmonize their own thinking with that of others. We need creative, innovalive people who are driven by the needs of their customers rather than by the elegance of the technology. Above all, we need people who realize the importance of life-long learning.

Die beginsels wat opgesluit lê in hierdie T-model vir dic opleiding van natuurwetenskaplikes op alle vlakke sal 'n nuwe dimensic toevoeg wat Suid-Afrika dringend nodig het. Daar is reeds hoëronderwysinrigtings wat hierdie filosofic in opleidings- programme op voor- en nagralidse vlak implemented. Ilier word veral verwys na technikons en enkele natuurwetenskaplike lakultcite atan Suid-Alrikatanse universiteite. Datar lê egter nog baic werk voor en natuurwetenskaplikes kan hierin die leiding neem.

\section{KENNIS - PRODUKSIE EN BENUTTING}

Die vertrekpunt is dic volgende omskrywing van Navorsing en Ontwikkeling soos gebluik in dic Witskrif oor Welenskap en Tegnologie:

Navorsing en Ontwikkeling (N\&O) is kreatiewe ondersock, sistematies uitgevoer, wat lei tot 'n toename in wetenskaplike en tegnologiese kennis EN dit is die gebruik van kennis on nuwe toepassings oor die spektrum van wetenskap en tegnologie heen te ontwerp.

Hierdie omskrywing behoort wyd vertolk te word om basiese. strategiese, loegepaste en produkverwante navorsing en ontwikkeling in te sluit.

In die verlede is daar sterk $\mathrm{klem}$ gele op die cerste gedeelte vall hicrdie omskrywing in navorsingsprojekte en nagraadse studies in natuurwetenskaplike rigtings. Die algehele behoefte het egter sterker na die tweede gedeelte begin verskuif.

Alumed Bawa ${ }^{7}$ stel dit soos volg:

Let us ensure that our research system spans the terrain between lundamental science on the one hand and product-related science at the other. In my view a normal distribution would be a good one with the bulk of scientists and engineers being engaged in the middle applied area - where both innovation and directedness are present.

In die geval van lechnikons behoort die klem nog sterker op dic produk-en prosesverwante navorsing en ontwikkeling te wees tesame met die noodsalaklike oordrag en suksesvolle implementering van die resultate en produkte.

Hierdie standpunte stel geweldige uitdagings aan natuurwetenskaplikes in luulle rolle om by te dra tot kennisontginning en -benutting. asook in dic opleiding van studente in gevorderde nagraadse programme.

'n Tweede salak wat hierby annsluit, is die hereidwilligheid om in 'n spanverband bydraes to bepaalde prioriteitstemas en -lohusgebiede, dikwels in 'n multidissiplinêre omgewing, te lewer. In die huidige stryd om hulpbronne is dit nie langer vir SuidAfrika moonlik om navorsingskapasiteit in elke denkbare gebied te onderhou nie. In die bepaling van datardic prioriteitstemas en -lokusgebiede sal die gebiede wat van besondere belang vir die sosio-ekonomiese ontwikkeling, asook dic nywerheidsherstrukturering en -heropbou is, deeglik in ag geneem moet word. Die gedaanteverwisseling wat dic navorsingsondersteuningsprogramme van die Stigting vir Navorsingsontwikkeling (SNO) in 1995 ondergaan het (en nog steeds besig is om te ondergaan), was 'n beskeic poging om juis dít te bereik. Dit is van kardinale belang dat die inwoners van Suid-Afrika oonuig moet wees dat die navorsings- en ont wikkelingsprogramme en projekte wat met behulp van staatsfondse aan hoëronderwysinrigtings asook wetenskapsrade verrig word, vir hulle van nut is en tot hulle voordecl sal strek.

Die UNESCO-verslag " bepleit die sinvolle rasionalisasic van navorsings- en ontwikkelingspogings deur die openhartige koördinering en samewerking in strecksverband en oor landsgrense heen, asook die vestiging van netwerke van sentrums van deskundigheid. Hierdic benadering word sterk ondersteun en beklemtoon voortdurend die belangrikheid van ware 
vennootskappe en stratlegiese alliansies tussen hoc̈ronderwysinrigtings, welenskapsrade, handel en nywerheid en regeringstrukturc. Hierin is dic optimale benutting van kommunikasicen inligtingstegnologic van kardinale belang.

As deel van kennisontwikkeling en -benutting het natuurwetenskaplikes ook 'n belangrike rol om te specl in dic ontwikkeling, aanpassing, oordrag en diffusie van tegnologic. Gegewens dui egter daarop dat natuurwetenskaplikes nog weinig aandag hicraan geskenk het. In 'n onlangse navorsingsprojek aan Technikon Pretoria insake die faktore wat die ontwikkeling en vestiging van tegnologie in Suid-Alrika bepaal," moes respondente aandui wat die belangrikheid van bepaalde faktore vir' ' $n$ land is asook die rol wat dit in Suid-Afrika speel. Tabel 1 verstrek enkele resultate. Hierdie resultate toon duidelik die huidige agterstand in Suid-Alrika aan asook die gewysigde verantwoordelikhede van natuurwetenskaplikes en hoëronderwysinrigtings.

Daar word algemeen aanvaar dat patente 'n maatslaf is van die eflektiwiteit van 'n land se tegnologiese ontwikkeling, sy intellektucle kapitaal en van die bydraes van natuurwetenskaplikes en ingenicurs tot die ckonomiese ontwikkeling van 'n land. Daarom is dit uiters sorgwekkend dat die getal patente wat aan Suid-Alrikaners toegeken is van 1417 in 1992 to 858 in 1994 gedaal het.

Die publikasic SA Science and Technology Indicators $1996^{12}$ spreck ernstige kommer uit oor die minimale betrokkenheid van hoëronderwysinstellings, $\mathrm{en}$ in besonder technikons, op die gebied van patentering. Die outeurs is van mening dat patente primêr afkomstig behoort te wees van openbaresektor-inrigtings, en spesilick van technikons, wat beskou word as dic saadbedding vir innovasie. Die aandecl van Suid-Afrikaanse wetenskapsartikels in die ISI geïndekseerde vaktydskrilte het met $20 \%$ gedaal, van $0,6 \%$ in 1988 tot $0,48 \%$ in 1994. Dit is dus duidelik dat ons wêreldaandecl leitlik weglaatbaar is.

\section{GEVOLGTREKKINGS EN AANBEVELINGS}

Uit dic voorafgaande behoort dil duidelik te wees dat natuurwetenskaplikes voor groot uitdagings staan in hulle rol $10 t$ samelewingsontwikkeling. Dic opleiding van die mensekrag van die land om aan die nuwe eise en uitdagings wat gestel word, te kan voldoen, toegerus met wetenskaplike en tegnologiese kundigheid en vaardighede, is 'n geweldige groot taak. Daarteenoor is die bydraes van natuurwetenskaplikes deur navorsing $\mathrm{en}$ ontwikkeling, tot nuwe kennis, die toepassing asook die benutting van die kennis in nuwe prosesse, produkte en tegnologie netso belangrik vir suksesvolle samelewingsontwikkeling.
Natururwetenskaplikes moet self besluit of dit "business as usual" gaan wees, want dil is slegs deur hulle toewyding, entoesiasme en deelname wat bogenoemde doelwitte halalbaar sal wees

'n Hersiene strategie oor die rol en verantwoordelikhede van natuurwelenskaplikes in samelewingsontwikkeling is noodsaaklik - 'n strategie waarin dic bydraes van natuurwetenskaplikes 'n deurslaggewende faktor sal wees.

Deur kragte saam te snoer en op 'n pro-aktiewe wyse die leiding te neem, kan natuurwetenskaplikes 'n unieke bydrae lewer - al beteken dit dat opleidings- en navorsings- en ontwikkelingsprogramme drasties aangepas moet word.

Die SA Akademic vir Wetenskap en Kuns, tesame met sy Fakulteitsraad Natuurwetenskap en Tegnick, het 'n belangrike rol om satam met ander vemote die leiding hierin te neem.

Ten slotte, daar is groot waardering vir die werk van natuurwelenskaplikes in Suid-Alrika en die bydraes wat hulle lewer. Die sake wat angeroer is, moct as verdere stimulering dien vir hulle nougesette toewyding en ywer. Daardeur kan ons almal saam verseker dat Suid-Afrika 'n wenland sal wees.

\section{II'TERATUURVERWYSINGS}

1. (1995). The Taiwan Expericnes: Implications for South Africa, Pretoria.

2. (1996). White Paper on Science and Technology: Preparing for the $21^{\text {st }}$ century, Department of Arts, Culture, Science and Technology, Pretoria.

3. (1995). National Strategy for the development and promotion of small business in South Africa, Department of Trade and Industry, Pretoria.

4. (1997). National Research and Technology Foresight, Department of Arts, Culture, Science and Technology, Pretoria.

5. (1997). Dralt White Paper on Higher Education, Department of Education, Pretoria.

6. Fanaroff, B. (1995). The Role of Science and Enginecring in the RDP, Prestige Lecture, Johannesburg.

7. Bawa, A. (1995). The Excitement for Scientists and Engineers in South Africa in 1995. FRD. Preloria.

8. UNESCO (1995). Policy Paper for Change and Development in Higher Education.

9. Van Rensburg, D.J.J. (1997). Stratcgic Planning for New Directions in Education, Technikon Pretoria

10. Tooker, GL. (1996). Graduates for a Competitive Global Environment. Industry d Higher Education, October 1996, 271-274.

1 1. Du Preez, N., Van Eldik P., Möhr, M., Van der Wat1, I1. (1996). Factors Determining the Development and Establishment of Technology in Soulh Africa, Technikon Pretoria.

12. (1996). SA Science and Technology Indicators 1996. Foundation for Research Development, Pretoria

TABEL

\begin{tabular}{|l|l|l|}
\hline $\begin{array}{l}\text { Faktore wat die ontwikkeling en } \\
\text { vestiging van tegnologie beïnvloed }\end{array}$ & Belangrikheid vir 'n land & Rol in Suid-Afrika \\
\hline $\begin{array}{l}\text { Die beskikbaarheid van hoëvlak } \\
\text { tegnologiese menslike hulpbronne }\end{array}$ & $89 \%$ & $43 \%$ \\
\hline $\begin{array}{l}\text { Die rol van hoër onderwys in die } \\
\text { voorsiening van hoëvlak menslike } \\
\text { hulpbronne }\end{array}$ & $90,5 \%$ & $52,8 \%$ \\
\hline $\begin{array}{l}\text { Die rol van natuurwetenskaplikes en } \\
\text { ingenieurs in die nywerheid }\end{array}$ & $72,7 \%$ & $37,1 \%$ \\
\hline
\end{tabular}




\title{
Klonering: 'n wetenskaplike en etiese perspektief
}

\author{
H. Huismans \\ Departement Genetika, Fakulteit Biologiese en Landbouwetenskappe \\ Universitcit van Pretoria, Pretoria, 0002
}

Ontrang 6 November 1997; anm'arr 26 November 1997

\section{UITTREKSEL}

Die artikel is gegrond op 'n lesing watrin enkele van die wetenskaplike en etiese aspekte wan betrekking her op die eerste suksesvolle klonering van 'n skatp ait die selle van 'n volwasse dier; behandel is. Die tegniese agtergrond van die eksperimemt word kortiks bespreek, instaitende 'n aantal moonlike redes vir die lae kloneringseffektiwiteit wat wargeneem is. Daar is aansienlike risiko's verbonde aan die klonering van diere uit gedifferensieerde, volwasse selle met 'n onsekere muasiegeskiedenis. In diereteelt kan die risiko's geregverdig word, ondat dit groot voordele kan inhon om geneties identiese afdrukke van enkele unieke diere te verkry. Dié diere kan gebraik word om 'n klein reelkudde op te bou waranit 'I groter nageslag dear meer konvensionele metodes onnikkel kan word. Hierdie voordele geld egter nie vir die klonering van mense nie en die werenskaplike voordele is beperk. Die klonering van mense is moonulik tegnies ook heelwat moeiliker as wat dit by skape die geval is en die risiko's wat dancan verbonde is só groot dat dit wetenskaplik onaunvarbaar is om enige eksperimente op die gebied le oonweg. Die mens is nie "I verbruikerswoonverp wat in diens van ander mense geproduseer kan word nie. Die klonering van diere is ook vergelyk met die reghologie om geneties-gemodifiseerde

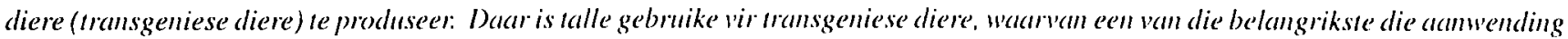
van transgeniese muise as modelle vir die studie van genetiese en ander siektes is.

\section{Anstract}

\section{Cloning: a scientific and ethical perspective}

The article is based on a lecture in which some of the scientific and ethical aspects of the first successful cloning of a sheep from the adult rissue of a full grown animal, were addressed. The techical background to the cloning experiment is briefly discussed as well as possible reasons for the very low cloning efficiency. The risks associated with cloning animals fiom differentiated, adult cells with an uncertain mutation history are very high. In amimal breeding these risks can be justified by the important application of making genetically identical copies of a number of rare, unique amimals that can form a small breeding stock from which these animals can be reproduced in a more conventional way. With respect to human cloning these advantages do not apply and the scientific value is limited. Human cloning is furthermore likely to be much more difficult than sheep cloning and the risks associated with stuch experiments so high that it is scientifically anacceptable to even consider amy experiments in this field. Humans are also not consumer products that can be produced to serve other people. The cloning of amimals is also compared to the technology to produce genetically modified animals (transgenic animals). There are again several important applications of transgenic animals but the most important of these is the unique use of transgenic mice as models for the sundy of genetic defects and other disorders in humans.

\section{INLEIDING}

Die ankondiging in Februarie 1997 dat dr. Wilmut en ander wetenskaplikes by die Roslin Instituut in Skolland daarin geslaag het om 'n skilap uit die uierselle van 'n volwalsse skalap te kloneer, het skokgolwe deur die welenskaplike wêreld en veral die algemene publick gestuur. Hierdie skok kan nie in die eerste plek toegeskryf word alan 'n vrees dat ons omring galan word deur duisende identiese skape nie, malar dit berus op die spekulasie dat as dit met skape gedoen kan word, die klonering van mense ook moontlik behoort te wees. Dit sou gestalte gee aan een van die bekendste wetenskapfiksienagmerries, naamlik die van 'n "Huxley's, Brave New World" waarin mense niegeslaglelik vermeerder word deur slegs die genetiese materiaal in die menslike selle te kopiecr. Die hipotese dat diere so vermeerder kan word, is natuurlik niks nuuts nie en die skalapklonering verteenwoordig slegs die eerste positiewe resultaat na 'n lang periode van meer as 40 jaar waartydens daar op een af ander wyse sonder veel sukses op die gebied geeksperimenteer is. Die lang periode van stilte het geleidelik die gerusstellende gedagte laat posvat dat die klonering van diere uit gedifferensiecrde selle nie werklik moontlik is nie. Die bedreiging van 'n "Brave New World" het vervaag. Die onlangse aankondiging het die perspekticl weereens riadikaal verander. Dic doel van hicrdic bespreking is om 'n paar van die beginsels wal die proses van klonering onderlê, te bespreek en te kontrasteer met dic beginsels wat betrokke is by die ontwikkeling van transgeniese diere. Elkeen van die verskillende benaderings het op sy beurt belangrike etiese implikasies vir die mens en daar sal probeer word om die gemeende wetenskaplike voordele op te weeg teen die etiese implikasies wal dit vir die mens, sy omgewing en die samelewing kan inhou.

\section{KI,ONE EN KI.ONERING}

'n Kloon kan beskryl word as 'n genelies identiese afdruk van 'n individuele organisme. Dit beteken die genetiese materiaal (die DNA), en dus ook die gene van die kloon, is identies aan die van die donororganisme waarvandaan die geneliese matleriaal verkry is. Gene is afgebakende dele op 'n veel groter DNAmolekuul wat die inligting of instruksies beval vir die sintese van proteiene. Hierdie protëiene bepalal die genelies oorerlnike eienskappe van 'n organisme. By soogdiere en alle ander eukariote organismes is die DNA-molckules in die kern van elke sel in die vorm van chromosome verpak. Daar word geskat dat daar ongeveer 100000 gene op die verskillende chromosome van die mens kan voorkom. Die geneliese verskille wat tussen mense waargeneem word, ontstaan omdat daar in 'n 
bevrugte eisel of oösiet 'n unieke kombinasie van die gene van elkeen van die twee oucrs plaasgevind het. Die kind toon groot ooreenkoms met sy ouers, malr is nogtans nooit genetics identies aan enige van dic twee nie. Die beste illustrasie van wat gebeur wanneer twee individue wel oor identiese gene beskik, word uit die vergelyking van 'n idenliese twecling verkry.

Dit is egter belangrik om te besef dat alle selle wat ha bevrugting deur seldeling vanal die enkele oösict tot sland kom, met enkele uitsonderings klone is van die oorspronklike oösict. Dit beteken dal elke sel in dic liggaanı, ondanks alle verskille in voorkoms en lunksie, nog steeds diesellde genetiese materiaal en gene sal beval as dic oorspronklike bevrugte oösiel. Op hierdie beginsel berus dic kloneringstegnologic. Selle van die lewer, die hart en die vel is dus almal klone van dieselide oösice en hevat identiese gene. Om dié rede behoort dit moontlik te wees om uil elkecn van dic seltipes weer 'n kloon van die oorspronklike individu te verkry. Die verskille tussen al die seltipes word deur' 'n differensiasieproses bepaal walarin verskillende gene in verskillende selle alan- of algeskakel word. 'n Baic belangrike vraag in die verband is of dic proses van differensiasie omkerbaar is. Kan gene wat reeds algeskakel is, weer geaktiveer word en geaklivecrde gene weer afgeskakel word? Die duidelikste antwoord hel tot dusver uit dic plantewêreld gekom waar dit redelik maklik is om volledige plante te herwin uit steggies van volwasse plantweefsel en sells uit enkele plantselle van verskillende weetsels soos blare of plantwortels. Elkeen wat 'n steggic in dic grond steck om 'n nuwe plant te kweek, is dus besig met klonering en klonering is dus niks nuuts of kontroversicel in dic naluur nic. Ons benutting van die plantewêreld berus in 'n baic groot mate op klonering. en baie van dic bome, plante en struike in ons tuine is almal klone van individucle plante wat cenmaal as uitsonderlik genoeg beskou is om tc kloncer. Dit is dus voor die hand liggend dat gevra sal word of dit ook op diere betrekking het. Is dit moontlik om 'n uitsonderlike plaasdier of 'n uitsonderlike trocteldier te klonecr sodat 'n identicse kopic daarvan gekry kan word?

\section{DIE SUKSESVOLLE KLONERING VAN 'N SKAAP}

Walarom het die navorsers in Skotland sukses behalal met hul kloneringseksperiment? Daar is natuurlik baic laktore wat 'n rol speel, maar cen daarvan is sekerlik dat die navorsingsgroep die beste ondervinding gehad ten opsigte van die tegniese en wetenskaplike beginsels waarop klonering berus. 'n Jaar te vore het hulle reeds daarin geslaag om skape te kloneer deur die genetiese matcriaal in 'n skaapoösict te vervang met dic genetiese materialal wat uit selle van 'n baic vroeë skaapembrio verkry is. Uit hierdic oösict is 'n skalap ontwikkel wat 'n genetiese kloon was van dic cmbriodonor. Omdat die embrionale selle nog nie werklik gedifferensicer is nic, het hicrdic eksperiment minder opskudding veroorsaak. 'n Jaar daarna het hulle egter die eksperiment herhaal met donorselle van 'n volwasse skaap.

Sonder om op die tegniese besonderhede self in te gaan, was die grondslag van hulle sukses die volgende eksperiment: Die uierselle van 'n ses jaar oue Fin-Dorsct-skaap is geïsolecr en in weetselkultuur aan die lewe gehou met slegs dic minimum voedingstowwe. Dic uithongering van die selle het veroorsaak dat die selle uit die normale delingsiklus in 'n ruslase, die sogenaamde $\mathrm{G}_{0}$-stadium beland het. In dié fase bly dic selle aan die lewe, maar sal nie decl nie en geen nuwe produkıe word gevorm nie. Terselfdertyd het hulle 'n oösiet van 'n ander lipe skaap, 'n Swartgesig-ooi, geisoleer en versigtig met 'n naald al die bestaande genetiese materiaal uitgesuig, sonder om te veel van die siloplasmagedeclte van die sel self te verwyder. Daarna het hulle die oösiet en die uiersel in die ruslase bymekatargebring en mel behulp van 'n elektriese puls die twee selle alangepor om te versmelt. Na die versmelting was die enigste genetiese materiaal in die oösiel afkomstig van die chromosome van die oorspronklike uiersel. Die sel is loegelaat om ' $n$ aantal seldeling te ondergaan en die klein embrio is daarna in dic Swartgesigooi teruggeplaas vir verdere ontwikkeling. Na die normale periode is 'n Fin-Dorset-skalap gebore wat geneties identies was alan die ma wat dic oorspronklike uiersel geskenk het. Die skalap het daarna dic bekende naam Dolly gekry.

Onder dic laktore wat tot die sukses van die eksperiment bygedra het, kan die uitgehongerde toestand van die volwasse uierselle moonllik ingereken word. Dit is moontlik dat selle walarvan die genetiese material in 'n rustoestand verkeer makliker by die nuwe oösietomgewing inpas en dal dit gevolglik makliker was om die proses van dilferensiasic om te keer. Dit is byvoorbeeld moontlik dat sekere van die proteiene en ander beheerfaktore wat in die selle voorkom om te verseker dat die sel as 'n uiersel funksioneer, in die rusfase afgebreek hel sodat die genetiese material reeds 'n deel van sy differensiasicbeheerlaktore verloor het toe dit met die eiersel versmelt is. 'n Ander laktor wall tot voordecl van die skaapklonering kon gegeld het, het te doen met die bevinding dat die differensiasic van 'n bevrugte oösiet by skape na die cerste delings heelwat stadiger is as by ander diere, soos byvoorbecld ' $n$ muis. By muise begin dic diflerensiasic reeds na die tweede deling (tweeselstadium) terwyl dit by skape eers na die vierde deling ( 16 -selstadium) plaasvind. Dil beteken dus dat die skalapuiersel se geneliese material heelwat tyd gegun is om by dic vreemde, nuwe omgewing van dic oôsiet aan te pas. By dic muis daartecnoor is daar nie so 'n aanpassingsperiode nie en die nuwe genetiese materiaal moet byna dadelik sy stempel op die sel afdruk. Dit is baie moontlik dat dit nie so maklik gebeur nie en dat dit een van die redes is waarom probleme mel die muisklonering ondervind is. Vir diegene wat die moontlikheid van mensklonering angsvallig dophou, kan dit gerusstellend wees om te weet dat die mens nader aan die muis as an die skaap is. Dil mag dus tegnies baic mociliker wees om mense te kloneer. Wat ook al die geval, die klonering van skape bly nog steeds tegnics baie moeilik en die elfektiwiteit van klonering is besonder laag. Uit 'n totaal van 277 selfusies het slegs een 'n suksesvolle kloon gelewer.

Daar kan baic redes vir die lac elfektiwiteit angevoer word. Een daarvan kan te doen hê met foute in die volwasse donorselle. Alhoewel die somatiese selle van 'n organisme genetiese klone is van die oorspronklike bevrugte oösiet het die selle tog oor 'n lectyd van bykans ses jaar 'n eie geskiedenis van verandering opgcbou. Tydens seldeling word daar dikwels klein foulc gemalk wat as mutasies bekend staan. Sulke mulasies kan ook deur verskillende eksterne faktore soos ultraviolet bestraling en blootstelling an chemiese stowwe aangehelp word. Die foute of mutasies word deel van die selle se genetiese material en word getrou van sel tot sel deur seldeling oorgedra. In dic betrokke uicrselle hoef die mutasies nic skadelik te wees nic, maar sodra dit van dic genetiese materiaal van dic ses jaar ouc selle verwag word om weer'n nuwe lewe te begin, is dit dalk 'n ander kwessic. Mutasies wat onskadelik in volwasse weefsel is, kan dus ' $n$ problecm word as die proses van differensiasic opnuut moet begin. Hierdie mutasies is willekeurig en daar kan dus nie vooraf voorspel of bepaal word of die klonering met ' $n$ normale of 'il reeds beskadigde sel uitgevoer gaan word nie. Die mulasies vind ook nic allecn in die chromosomale DNA plaas nic, maar ook in dic mitochondriale DNA. Mitochondriaorganelle kom in die sitoplasma voor en is verantwoordelik vir $90 \%$ van die energieproduksic in die sel. Hulle word normalalweg 
slegs van die moeder oorgeërl deur die mitochondria in die oôsiet. Mulasies in die organelle kan siektes veroorsak. Nal versmelting van die oösiel met die uiersel bevat die nuwe oösiet 'n unicke mitochondriasamestelling. In plaas van net die jong Swartgestgskaap-mitochondria is dialr nou ook reds verouderde Fin-Dorset-mitochondria walarvan sommige foutc of mulasies kan bevat wat nadelig vir die kloon kan wees.

Al hicrdic nadelige mutasic-elfekte kan moontlik oorkom word deur slegs 'n groter antal lusies uit te voer. Die regte produk kan nog steeds gekry word, al is dit dan teen die koste van 'n lac kloneringselfektiwiteil. As dieselfde eksperiment egter' by mense uitgevoer sou word, sou dit 'n onaanvalarbare probleem skep omdat klone gegenereer kan word wal aan onvoorspelbare gebreke onderhewig mag wees. Dit is duidelik nie die soort risiko waaraan mensklone onderworpe mag word nic.

'n Tweede soortgelyke probleem is dat selle, ondanks akkurate deling, log onderworpe is ann veroudering. Die veroudering is deels as gevolg van chromosomale en mitochondriale mutasies, matar baic ander laktore kan egler ook betrokke wees, soos onder meer die verkorting van telomere in somatiese selle. Die ente (telomere) van 'n chromosoom kan nie so akkuraal verdeel as die res van die chromosoom nie. Die chromosoom word moontlik sell's met elke deling 'n klein bietjic korter omdalt die ente onvolledig gedupliseer word. Daar is metodes om vir die foute te kompensecr, maar dit is goed bekend dat daar groot variasic in die lengte van telomere in verskillende weefsels en sells in selle van dieselfde weelsel kan voorkom. Omdat daar nie belangrike gene of inligting by die ente gelee is nic, is dit nie by jong selle 'n groot probleem nic, maal' na baic delings kan die telomere dalk só verkort dat dit wel 'n problecm skep. Selle kan dus tekens van ouderdom toon net soos 'n dier in sy geheel ouer word. 'n Interessante vraag sou wees of Dolly, omdal sy gekloneer is uit selle wat reeds ses jaal "oud" is, ses jaar van haar normale lewe sal moet inboet. Net die tyd sal leer wat die antwoord op dic vraig is.

Dit is dus duidelik dat daar nog baie onopgeloste vac oor die elfekliwileit van klonering en die ewe belangrike risiko's wat geneem word, bestaan. By diere kan die voordele van klonering moontlik so groot geag word dat dit kompenseer vir moontlike nadelige gevolge. By die mens daarteenoor plaas dit 'n onaanvaarbare wetenskaplike las op die hele proses.

\section{DIE GEBRUIK VAN DIEREKI ONERING EN ETIESE IMPLIKASIES}

Die belangrikste motivering vir die navorsing op skaapklonering was die groot behoefte om 'n identiese genetiese afdruk te maak van diere wat mel geweldige hoë koste deur middel van genetiese manipulasie of genetiese ingenicurswese ontwikkel is. Sulke sogenaamde transgeniese diere is potensied van groot ekonomiese waarde, maar baic van die voordele kan verlore gaan as 'n nageslag van die diere deur normale telingsprosesse verkry moet word. In dié opsig is sulke diere dus soos baie skaars, unicke plante wat deur klonering vermeerder behoort te word om hul voortbestaan te verseker. Dic belangrikste voordecl van klonering is dus om spesifieke diere te vermeerder met behoud van al die vooraf bekende en geëvaluecerde geneliese cienskappe. Op dié manier kan grool telingsvordering in 'n baic kort tyd met groot kostebesparing gemaak word. Dit stel telers in staat om 'n kernkudde van miskien vyl' of' tien diere deur klonering op te bou waaruit 'n groot nageslag deur meer konvensionele teling geproduseer kan word.

Dieselfde benadering mag ook vir die bewaring van bedreigde spesies geld. Daar word byvoorbeeld min sukses behaal met konvensionele teelprogramme om die behoud van die Panda te verseker. Dit mag dalk moonllik wees om 'n Pandal te kloneel. Dit is sekerlik nic die ideale benadering om die voortbestaan van die Panda te verseker nie omclat dit belangrike genetiese varliasic inperk. Noglans is die behoud van 'n geklonecrde P'andal steeds veel beter as die algehele verlies daarvan.

Daar is ook groot watarde aan klonering uit 'n mecr akademies wetenskaplike perspektiel. Die moontlikheid on 'n groot almtal geneliese klone van dieseldue volwasse dier te bekom, mag wetenskaplikes in stalat stel om belangrike vrae oor die difterensiasieproses self te beantwoorl. asook om alindag aan fundamentele vrac oor aspekte soos selveroudering en die bydrae van sitoplasmatiese eflekte (soos bv. mitochondria) te gee. Sulke geneties identiese diere is ook die ideale manier on die elfek van dic omgewing op die ontwikkeling van ' $n$ dier te bestudeer. Dit is goed bekend watter belangrike rol identiese Iweelinge speel om by die mens die bydrae van ongewing tot persoonlikheid, intelligensie en ander faktore te besiudeer. 'n hlele paneel van geneties identiese individue sou 'n baie belangrike bydrae op dié nalvorsingsgebied kan maak.

Dit soü egler misleidend wees om te probeer voorgee dall daar nie ook wetenskaplike en eliese bedenkinge oor diereklonering bestan nie. Een ooglopende gevaar is dat klonering 'n athame in genetiese diversiteil mecbring. Dit is op die lang termyn nadelig vir die oorlewing van die betrokke bevolking. Die moontlike gevaar hicrvan word egter getemper deur die realiteil dal klonering waasskyılik altyd tegnies duur en oncllekticl galan wees sodat dit nooit, soos by baic plante, normale voortplanting sal vervang nie. Dit moet dus altyd as 'n aanvullende hulpmiddel in diereteling beskou word.

Is dit regverdigbalar om diere te kloneer vir eie, selisugtige en dikwels suiwer ekonomiese belang? Daar kan beweer word dat ons die natuur sy gang moet laat gaan en dat klonering die gevalar inhou dat dit die mens versterk in sy behoefte om die omgewing vir sy eie voordecl uit te buit. Dit is 'n mocilike salak. maar dit kan belwylel word of klonering werklik vecl aan die huidige situasie gatn verander. Die mens teel diere al vir eeue lank om in sy eie, selfsugtige behoeftes te voorsien. 'n Kloon van 'n skalap of 'n ander dier is nie meer onnatuurlik as die produkle wat deur eng-gefokusde diereteling $10 t$ stand gebring word nie. 'n Hond is nie werklik meer 'n "natuurlike" produk nic maar reflekteer die selfsugtige behoeftes wat die mens alan 'n troeteldier kan stel. Sommige mense het behoefte aln klein, wollerige skoothondjies terwyl ander groot, gevarlike waghonde met skerp tande verkies. Ilondetelers het verseker dat die "produkle" beskikbaar is. Diesellde geld vir alle huisen plaasdicre wat ons vir ons gebruik toc-eicn. As dit eties aanvalubaar is om sulke dicre te teel en te gebruik, hehoort klonering, as 'n baic ellektiewe manier om 'n gocie produk te verseker, ook ctics alanvaarbarar te wees. Indien daar wel 'n redelike beswatar teen die benadering is. moel daar indringend na al die aspekle wall die normale gebruik van ons dierebevolking raak, gekyk word. Ten laaste is dit belangrik om te oorweeg of die gekloneerde dier self benadeel word. As die legnologic self nie die dier benadeel nie, hel die dier self sekerlik geen probleme met die feit dat hy of sy 'n kloon is nic. Na alle walarskynlikheid is Dolly net so gelukkig as halar normail geproduseerde eweknic. Dit is veral in dic opsig dal die eliese oorwegings van mens- en dierklonering radikial van mekaar kan verskil.

\section{DIE KLONERING VAN MENSE EN ETIESE OORWEGINGS}

Die eerste en miskien belangrikste vraag is of dit moontlik sal wees om mense te klonecr. Alhoewel dil wellik verbied word, is klonering uit embrioselle 'n baie sterk moontlikheid. Voordal 
differensiasie begin, is die probleme en risiko's wat by die klonering van die genetiese material belrokke kan wees baic kleiner. Klonering vanal sclle van 'n volwasse individu is egter 'n ander saak. 'Ten ecrste is daar by die mens die reeds genoemde probleme mel die vroeë differensiasie van selle tydens die eerste seldelings. Die mens is meer soos die muis en klonering van die muis was tol dusvêr nog altyd onsuksesvol. Klonering van mense uit volwasse weelsel kan dus tegnies baic moeilik wees en die elfekliwiteil kan nog vecl laer wees as die reeds baie lac effekliwileit van skaapklonering. Nog belangriker is egter die onaanvaarbare risiko wat sulke klonerings kan inhou. Daar is reeds verwys na die probleme wat verouderde selle en selle met 'n onsekere mutasiegeskiedenis kan inhou. Wat gaan met mislukte kloneringseksperimente, en in besonder klone met gebreke wat nic voorgeboortelik opsigtelik was nie, gebeur? Daar is beslis nie 'n etiese manier waarop daar van die twyfelagtige kloneringsprodukte ontslae geraak kan word nic. Dit is dus moeilik om te glo dat enige wetenskaplike bereid sou wees om dic soort risiko te loop selfs al sou dit deur die wet veroorloof wees. Net die gedagte aan die tipe wanpraktykeise wat so 'n kloon sou kon instel om vir 'n bepaalde geneticse defek te kompenseer, is genoeg om belangstelling in die tipe wetenskaplike navorsing te kelder.

Uit 'n bloot wetenskaplike perspekticl' is dit dus recds duidelik dat die klonering van mense onaanvaarbaar is en so sal bly. Die wetenskaplike risiko is te groot. Indien die tegniese redes egter buite rekening gelaat word en ons aanvaar dat dit wel moontlik kan word om ' $n$ veilige klonering uit te voer. hoe beînvloed dit dic verdere etiese oorwegings"? Soos reeds by dierklonering bespreek, is dit duidelik dat klonering slegs gerig is op die dier as verbruikersvoorwerp. By die mens sou dit niks anders wees nie. Niemand wil 'n mens kloneer ter wille van dic belang van die kloon self nic. Die enigste rede warom mense ander mense sou wou klonecr, het te doen met 'n begeerte om iets te dupliseer wat presies aan 'n bepaalde, selfsugtige behoelte voldoen. Hierdic behoefte kan die egomania van 'n individu reflekteer of gerig wees op dic obsessic om 'n individu waarvoor daar groot bewondering mag bestaan, te laat voortleef. Wat ook al die moticf, in alle gevalle bly dit 'n hunkering na dic "verbruik" van 'n persoon. Dit is dus niks anders as 'n vorm van slawerny nie en dit bly onder alle omstandighede etics onaanvaarbaar. Daar kan maklik beweer word dat as dit moontlik was om weer 'n Einstein of 'n Mozart te kloneer, die voordele al die nadele en gevare sou kon oorbrug. Dit is sekerlik waar dat 'n "nuwe" Mozart met 'n lang produktiewe lewe 'n ongelooflike musikale skat aan dic mens kon nalaat. Die realiteit is egter anders. Mozart was 'n produk van beide geniale musikale gene en sy besondere omgewing. Sonder die omgewing van 'n bepaalde vader, musikale prioriteite, regeringsbelangstelling en ander aspekte kon dinge baic anders verloop het. 'n Kloon van Mozart sou in vandag se samelewing dalk baie ander prioriteite hê. Meer nog, as almal angsvallig sit en wag op sy ecrste sonate mag hy rebels weier om aan 'n klavier te raak. Niks is voorspelbaar nie. Die mens as individu is ' $n$ unieke samestelling van gene en omgewing. Selfs klone van 'n Hitler wat in 'n konvensionele Pretoriase voorstad opgegroci het, $\mathrm{mag}$, anders as wat die wetenskapsfiksie dit wil hê, verkies om eerder as 'n bedeesde klerk of universiteitsdosent sy loopbaan te vind. Anders as by dicre sou die bewussyn by dic mens dat hy of sy bloot geproduseer is om 'n kloon van 'n ander uitsonderlike of geliefde individu te wees 'n ondraaglike las op so 'n kloon plaas. Die kloon self gaan baie groot besware hê tcen die feit dat hy as 'n kloon gedupliseer is en dit alleen maak dit eties onaanvaarbaar.

Net so min as wat die sukses van dic klonering van mense voorspelbaar is, is dit moontlik on te voorspel of dit ooit sal gebeur. Wetenskaplik en wetlik is die tecenstand teen sulke eksperimente egter so sterk dat dit tans baic onwarskynlik lyk. Dit sou dus onmoontlik wees om van enige van dic erkende metodes gebruik te maak om sulke eksperimente te befonds of te publiseer. Dic klonering van mense is ook as metode nic van besondere wetenskaplike waarde nie. Die klonering van 'n skaap was baic belangrik omdat dit 'n nuwe metode en 'n nuwe beginsel geïllustreer het. Dic klonering van mense illustreer bloot dieselfde wetenskaplike beginsel, loegepas op 'n ander spesic, en dit het as sulks meer gevoels- as werklike wetenskaplike wilarde. Soos aan die begin bespreek, is dic klonering van diere in 'n groot mate gemotiveer deur die behoefte om geneties identiese aldrukke van transgeniese diere te mak. Die toepassing geld natuurlik nie vir mense nie, maar transgeniese dicre het wel vir die mens 'n belangrike gebruiksvoorwerp geword en dit is gevolglik wel belangrik om die verband tussen klonering en transgeniese diere van nader te beskou en te wys op die voordele en etiese oorwegings wat by die gebruik daarvan geld.

\section{TRANSGENIESE DIERE EN KLONERING}

Dic ontwikkeling van transgeniese dicre berus ook op die gebruik van 'n kloneringstegnologie. In dić geval egter nic die klonering van heel organismes nic, maar wel dic klonering van gene. Geenklonering en rekombinante DNA-tegnologic dateer uit die vroeg sewentigerjare en berus op die vermoë om identiese afdrukke van spesifieke gene te mak en te isoleer. Hierdie gene mag inligting bevat vir die sintese van proteiene van kommersiële of wetenskaplike waarde. Dic ontwikkeling van transgeniese diere berus daarop dat sulke gekloneerde gene by die geneticse materiaal van 'n oösiet ingelas word sodat die transgeniese dier wat daaruit ontwikkel cienskappe bykry wat hy nie normaal weg sou hê nie. Die cienskap is dikwels dat die dier nou oor die vermoë beskik om sckere unicke proteiene te produseer wat van kommersiële of ander waarde kan wees. So byvoorbeeld is daar ' $n$ transgeniese bok geproduseer wat die menslike antitrombien-proteïen wat vir blocdstolling gebruik kan word, produsecr. Daar is 'n bees ontwikkel wat menslike alfa 1 -antitripsien in dic melk afskei wat vir sistiese fibrose gebruik kan word. Ook dic melkkwaliteit van beestc is verbeter deur 'n transgenicse koci te ontwikkel wat die menslike alfalaktalbumien in dic melk afskei wat as 'n gocie voedingstoevoeging beskou kan word. Varke wat die menslike bloedfaktor VIII en fïbrogeen in die melk produsecr, is ook al ontwikkel. Dit is nie die doel van die bespreking om in diepte by dic wetenskaplike metodick waarmec transgeniese diere geproduseer word, stil te staan nic maar ter aansluiting by die dierkloneringsmetodick is ' $n$ paar opmerkings wel ter sake. Die metodiek berus weereens op die modifikasic van 'n bevrugte oösict. Anders as om dic geneticse materiaal in sy geheel tc verwyder en weer te vervang met die van 'n ander sel, word in hicrdic geval geklonecrde gene van 'n bepaalde tipe, soos byvoorbeeld die geen wat die inligting vir die sintese van menslike alfa-laktalbumien bevat, lot die oösiet toegevoeg. Dic geen word daarna by die chromosome ingelas en die oösiet word na ' $n$ aantal delings teruggeplaas en toegelaat om te ontwikkel. Dic nuwe transgeniese dier wat so geproduseer word, het 'n unicke cienskap bygekry wat weer na dic volgende geslag oorgedra kan word. Die koste aan dic ontwikkeling van sulke transgeniese diere en in besonder die groter plaasdiere, kan egter miljoene rande beloop en dit dien as motivering vir die klonering van sulke diere.

Die belangrikste huidige gebruik van transgeniese diere is egter nie vir die produksic van unicke farmaseutiese produkte nie, maar wel die moontlikheid om transgeniese diere te produseer wat as 
modelle kan dien vir die studic van enige van 'n baie groot verskeidenheid genetiese en ander sicktetoestande. Net soos dit moontlik is om nuwe gene by die genetiese matcriaal van 'n oösiet in te las, is dit ook moontlik om op hoogs selekticwe wyse bestaande gene te inaktiveer. 'n Groot aantal verskillende siektetoestande of kenmerke van 'n dier wat met 'n bepaalde geen geassosieer kan word, kan op die manier nageboots en bestudecr word. Meeste van die werk is met muise gedoen en dic lys van muise waarvan bekende gene geïnaktiveer is ol' met gene vervang is wat op 'n bepaalde manier gemuteer is, is baic groot. Daarr is onder meer transgeniese muise ontwikkel wat sickteloestande hel wat met Alzheimer se siekte ooreenkom. Daar is muise met malkocisiekte, muise mel gewigsprobleme, muise sonder enige weerstand teen kanker, muise wat nie langer oor 'n immunologicse verdedigingsmeganisme beskik nie en self's muise wat die mees basiese moederinstink om na hulle kleintjies om te sien, verloor het. Hierdie tipe muise het van onskatbare waarde geword in mediese navorsing en skep geleenthede om sekere siektetoestande te ondersock wat op geen ander manier bestudeer kan word nic. Dit is voor die hand liggend dat alles wat in muise walargeneem word nie net so op die mens van tocpassing is nic, maar nogtans gee dit vir die mens in baic gevalle die eerste blik op die bydrac wat sekere gene tot die fisiologie en oorlewing van 'n dier kan maak. Op dié manier is daar reeds baic bygedra tot die studie van geenfunksies.

Die moontlikheid om muise met bepaalde genetiese delekte te produseer, stel wetenskaplikes verder in stat om diagnostiese en terapeutiese hulpmiddels te ontwikkel om dic probleme dic hoof te bied. In die verband is die ontwikkelinge op die gebied van geenterapie baic toepaslik. In geentcrapie word probeer om foute wat aan defekte gene toegeskryf kan word, reg te stel deur die korrekte weergawe van die geen tot sekere selle buite of binne-in die liggaam toe te voeg. Die benadering produsecr nic transgeniese diere nie maar kan ' $n$ unicke oplossing bied om spesifieke ensiem- en ander tekortkominge aan te vul. By die mens is daalr mel behulp van geenterapie besondere vordering gemilak met siekles wat aan 'n immunologiese gebrek toegeskryl' kan word. Baie ander moontlikhede word tans ondersock. Die benadering maak weereens gebruik van geenklonering, malar is eties baic verskillend omdat geen permanente verandering in die geslagselle betrokke is nie. Die groot gevare en risiko's is dus aansienlik verminder.

\section{ETIESE OORWEGINGS: 'TRANSGENIESE DIERE}

Die etiese oorwegings wat by die ontwikkeling van transgeniese diere geld, toon 'n sterk oorenkoms met dic oorwegings wat by die klonering van diere gegeld het. Daar is voordele maar ook, soos met alle tegnologicè, die moontlikheid van misbruik. Weereens is daar egter streng wetenskaplike beperkinge ter sake. Dic ontwikkeling van transgeniese mense is byvoorbeeld in beginsel heeltemaal moontlik, maar die onaanvaarbare wetenskaplike risiko en die he effektiwiteit van die proses maak dit wecreens 'n onaanvaarbare wetenskaplike eksperiment. Daar is ook in alle lande streng wetlike beperkings op die tipe eksperimentering. Alhoewel die tegnologie nou al vir heelwat meer as tien jaar goed bekend is, kan redeliker wyse angeneem word dat sulke eksperimente nog nooit met mense uilgevoer is nie. Die lipe wetenskaplike kontrole is gerusstellend en bevestig weereens dat welenskaplikes nic maklik bereid is om sulke risiko's met mense aan te gaan nic. Daar kan slegs gehoop word dat dieselfde konserwaticwe beginsels ook ten opsigte van klonering van diere en mense gaan geld.

\section{LITERATUURVERWYSINGS}

I. Campbell, K.H.S., McWhir, J., Richic, W.A., Wilmut, I (1996). Nature, 380, 64-66.

2. Wilmut, I., Schnicke, A.E., McWhir, J., Kind, A.J., Campbell, K.H.S. (1997). Nature, 385, 810-813. 


\title{
Proefskrifte en Verhandelings
}

\section{'n Opleidingsmodel vir die integrering van rekenaar- en navorsingsvaardighede op hoëronderwysvlak}

\author{
A.S. Blignaut \\ (Proefskrif vir die Ph.D.-graad in Rekenaargesteunde Onderwys; promotor: prof J.G. Knoetze) \\ Departement Didaktick, Universiteit van Pretoria, Pretoria, 0002
}

\begin{abstract}
Die belangrikste rol van tegnologie in enige gemeenskap is dié van ' $n$ hulpmiddel, dit wil sê 'n wyse waardeur kennis, materiale en energie nuttig aangewend kan word tot voordeel van die gemeenskap. Enige verandering in tegnologic beïnvloed dic persoonlike en sosiale vlakke van almal in die gemeenskap, ıerwyl die behoeftes van individue en gemeenskappe op hulle beurt weer bepaal watter tegnologieé hulle direk met dic samelewingsomgewing verbind. Dic susksesvolle gebruik van tegnologie deur 'n gemeenskap impliseer verhoogde bestuursvaardighede van dic gebruikers in dic effekticwe locpassing daarvan. Sosiotegnologiese en sosiokulturele alanpassing is 'n voortdurende proses wat groot uitdagings aan dic ontwerp van tocpaslike onderwys- en opleidingsisteme stel. By die beskouing van hierdie evolusionêre proses, kom 'n mens tot dic besef dat dic kapasiteit om te ontwikkel en aan te pas onbeperk is. Modelle vir toepaslike onderwyssisteme met intelligente tegnologiese toepassings vir spesifieke sosiokulturele gemeenskappe behoort ontwerp te word ter wille van dic oorlewing van alle gemeenskappe binne dic snel ontwikkelende wêreldsamelewingsgemeenskap.
\end{abstract}

Die ontplooiing van 'n nuwe sosiale kultuur het reeds met dic politieke cn sosiale veranderinge wat op 27 April 1994 in SuidAfrika geinisieer is, op alle terreine sigbalar geword. Veranderinge in onderwys en opleiding is geen uitsondering nie en dic vooruitskouing van die veranderinge vir dic volgende paar dekades word in die Witskrif oor Onderwys (Departement van Onderwys, 1995) uitgestippel.

Die doel met hierdie ondersock was om 'n opleidingsmodel te ontwerp wat studente, ingeskryf vir 'n voedselvakkursus op die hoëronderwysvlak (Voedsel 310), in staat sal stel om rekenaaren navorsingsvaardighede, onderliggend aan toepaslike berocpsverwante bemarkbare bekwaamhede, te bemeester, tot voordeel van 'n veranderende sosiolegnologiese kultuur, binne die raamwerk van 'n veranderende en demokratiscrende Suid-Afrika.

Die navorsingsdoel is vanuit ' $n$ idee (persepsie, doclstelling) geïniseer dat dic opgawes vir opleiding, soos uitgestippel in dic Witskrif oor Onderwys en dic Nasionalc Kwalifikasieraamwerk (RGN, 1995), die eise vanuit dic samelewingsomgewing en die kontekstuele opleidingsuitkomste vir huishoudkunde-opleiding as basis vir die opleiding van studente met betrekking tot die voedselvakkursus moes dien. Aan die hand van aksienavorsingsprosedures is hierdie idec tydens 'n voorloperstudie verfyn tol 'n voorlopige opleidingsmodel waarin voorgestel is dat rekenaaren kontekstuele vaardighede geintegreerd ontwikkel behoort te word met die oog op die bemagtiging van die individu met beroepsverwante bemarkbare bekwaamhede.

Met die oog op onmiddellike ontwikkeling en verbetering van die opleiclingspraktyk, is die voorlopige opleidingsmodel langs die weg vall aksienavorsing geimplementecr. 'n Toepaslike studentenavorsingsprojek is geïdentifiseer en deur middel van oriëntering, verkenning, beplanning, implementering en analise en beoordeling is dic opleidingsuitkomste met betrekking tot die uilvocring van dic studentenavorsingprojek beoordeci. Dic studente het rekenarvaardighede relevant tot Microsofi Office 4.3 (Windows 3.1 -gebaseerd) alangeleer en het deur middel van 'n konstruktivisticse brongcbasecrde opleidingsbenadering die kontekstuele vaardighede van die Voedsel 310-vakkursus koöperaticl bemeester. Die prestasic-uitkomste van die studente met betrekking tot die navorsingsprojek is op 'n verskeidenheid van wyses (rekenaarmatig, visueel en papiergebasecr) tydens 'n grocpseminaar gekommunikeer.

Die ingesamelde data en studente-evaluerings met betrekking tot die aanbieding van dic vakkursus is geanaliseer. Alhoewel die studente dic konstruktivistiese brongebaseerde opleidingsbenadering mocilik gevind het, het hulle dic koöperatiewe demonstrasic van prestasic-uitkomste sinvol beleef, maar het die koöperatiewe en konstruktivistiese opleidingsbenadering oor die algemeen intensiel, tydrowend, uitdagend en tegelyk verrykend ervaar. Daar kan derhalwe afgelei word dat waardetoevoeging 'n unicke, onderskeidende kenmerk van die Voedsel 310vakkursus, aan die Departement Huishoudkunde, Universiteit van Pretoria, was.

Aspekte en declaspekte van dic opleidingsgebeure is gečksplisitcer en geïnventarisecr. Hierdie inventaris is gebruik om 'n voorlopige klassifikasie ten aansien van die konstruksie van die opleidingsmodel saam te stel. In die konstruksie van die model is die pragmaliese en spesifieke betckenisse (behoelites van die persone vir wie die model ontwikkel is) in berekening gebring. As finale stap van die vereenvoudigde benadering tot die integrering van rekenaar- en navorsingsvaardighede op die hoëronderwysvlak, is 'n opleidingsmodel gekonstrueer.

Hierdic model het betrekking op die volgende opleidingsaspekte, naamlik die

opleidingseise vanuit die samelewingsomgewing en beleidmakende vlakke van onderwys en opleiding;

opleidingsrasionaal vir die betrokke vakkursus;

kurrikuleringsproses met betrekking tot dic vakkursus;

vereistes met betrekking tol dic opleidingsinfrastruktuur aan dic betrokke hoëronderwysopleidingsinstansie;

opleidingsbenaderings wat gevolg word in die aanbieding van dic vakkursus. 


\title{
Die invloed van bemesting op die kwantiteit en kwaliteit van Digitaria eriantha Steud. in semi-ariede gebiede
}

\author{
I.F. Reckling \\ (Verhandeling vir die M.Sc.-graad; leier: prof. G.H.J. Kruger) \\ Departement Plant- en Bodemwetenskappe, Polchelstroomse Universiteit vir Christelike Hoër Onderwys, \\ Potchel'stroom, 2520
}

In potproewe is bevind dat die twee geëvaluecrde kultivars van D. eriantha, Irenè en Tip Top, se biologiese fosfaatbehoelte eenders is. 'n Sandkleigrond met 'n residuele grondfoslaatwaarde van $10 \mathrm{mg} \mathrm{kg}^{-1} \mathrm{P}$ (Bray I) mel' 'n pll 5-7 $\left(\mathrm{H}_{2}(0)\right.$, blyk om genoegsame fosfat vir normale grocivereistes te verskat. Hierdic norm is egter slegs van toepassing indien $D$. eriantha nie alan meganiese ontblaring blootgestel word nie.

Meganiese ontblaring van $D$. eriantha veroorsalak dat ongeveer $(0,39 \% \mathrm{P}, 2,94 \% \mathrm{~K}, 0,51 \% \mathrm{Ca}$ en $0,64 \% \mathrm{Mg}$ met elke ontblaring verwyder word. D. eriantha onderworpe alan drie meganiese ontblaringsintervalle, tydens die reproduktiewe fase, het by ' $\mathrm{n}$ residucle losfaatstatus van ongevecr $15 \mathrm{mg} \mathrm{kg}^{-1}$, dic hoogste droëmatcriaalopbrengs gelewer. Dic grondkaliuminhoud het weens ontblaring en uilloging egter gedaal en mag indirek verantwoordelik wees vir prolienakkumulasie in die wortels van $D$. eriantha.

Onder droëlandtoestande het stikstolbemesting die droëmateriaalproduksie statisties betekenisvol $(\mathrm{P}<0,05)$ verhoog. Dic verlaging in grond $\mathrm{Ca}, \mathrm{Mg}, \mathrm{K}$ vlakke met gepaardgaande daling in $\mathrm{pH}$, kan egter ook aan stikstolbemesting loegeskryf word. $D$. eriantha bemes met KAN het egter deurgaans $(\mathrm{P}<0,05)$ hoër produksies gelewer by dieselfde stikstofpeil, in vergelyking met persele wat ureumstikstol ontvang het. Ureum was moontlik meer onderhewig aan stikstofverliese as gevolg van moontlike perkolasic, denitrifikasic en/ol vervlugliging. Nitraatstikstof verbind deur middel van kovalente bindings aan kalsiumione en bevorder daardeur die verplasing van kalsiumione uil dic grond. Persele bemes met KAN het statisties betekenisvol $(\mathrm{P}<0,05)$ laer kalsiumvlakke bevat. In teenstelling hicrmec word ammoniak vir translokasic na die aminosure, glutamaat en aspartaal omgeskakel. D. eriantha bemes met urcum het dubbel die konsentrasies van die twee genoemde aminosure bevat. Dit implisecr dat ureum onder genoemde omgewingstoestande nic na nitraat verander het nie, maat as ammonium opgeneem is.

Dekversies het in die laat winter statisties betckenisvol $(P<0,05)$ meer lek verbruik tydens die benuting van $D$ ). eriantha staandehooi. Die loename in lekverbruik kan toegeskryf word aan die claling in die kwaliteit weens lignilikasic, denaturering, translokasic en blaarverlies van die staandchooi, soos aangedui deur die chemiese analise van ruproteïen, droëmaterial in vitroverteerbaarheid en die katioon-konsentrasies van plantmaterial. Daar is bevind dal dic residuele grondstit.stolkonsentrasic hoë. was in persele wat nic onderhewig was aan 'n somer-snyaksic nic.

Hoewel nie bewys deur die chemiese analise van plantmateriaal, of afleibaar uit diereprestasic vir die 1993- en 1994 winterseisoen nie, het die toemaak van kampe na bewciding of hooimaakaksies dic kwaliteit van staandehooi bevoordecl. Laat toediening van kunsmis, gekombineer met laat reënval was verantwoordelik vir posiliewe daaglikse massatoename in die 1995-winterseisoen. Ongesnyde kampe is egter gekenmerk deur hoër oorgedraagte residuele grondstikstof. Gevolglik sal verliese weens hooimakk in berekening gebring moet word om 'n sinvolle stikstolbemestingaanbeveling te kan makk, indien beweiding of sny van kampe wel loegepas is.

Ekonomies het somerbeweiding van $D$. eriantha meer voordele in terme van gewigstoename, in vergelyking met 'n winterbenuttingstelsel. Indien 'n winterbenuttingstelsel wel gevolg word, is vroeë winterbenutting voordeliger, soos dic statistiese laer lekinname $(\mathrm{P}<0,05)$ wat veroorsaak word deur dic daling in kwalitcit, aangetoon het.

\section{Evaluering van'n rietbedding as sekondêre behandeling vir huishoudelike afvalwater met'n nywerheidskomponent}

\author{
A.M. van der Walt \\ (Verhandeling vir die M.Sc.-graad; leier: prof. B. Pieterse)
}

Departement Biochemie en Mikrobiologie, Potchefstroomse Universitcil vir Christelike Hoër Onderwys, Potchefstroom, 2520

Die doel van hierdic ondersoek was om 'n Vrywaterstelsel (VS)rietbedding te evalueer as sekondêre behandelingsfase vir 'n gemengde uitvloeisel wat huishoudelike sowel as nywerheidsafvalwater bevat het. Primêre behandeling vir die afvalwater het bestaan uit 'n geaktiveerde slykproses, gevolg deur chlorinering en veroudering in ' $n$ dam. Om verandering in die afvalwatergehalte te bepaal, is die konsentrasie van sleutelveranderlikes met behulp van standaardprosedures gemeet. Resultatc het aangetoon dat, hoewel die vlak van besoedelingstowwe groolliks deur primêre behandeling verminder is, die konsentrasic van totale gesuspendeerde vastestowwe, chemiese suurstofaanvraag, nitrat en foslaat steeds dic Gehaltestandaarde vir Afvalwater en Uitvlocisels oorskry het.

In die VS-rictbedding is die vlakvloci van afvalwater oor dic oppervlak van 'n beplante kanaalbedding onderbreek deur pocle, wat ingesluit is om dic retensic van die afvalwater in dic stelsel 
te verleng. Die doeltrelfendheid van besoedelingstofverwydering is 'n funksic van dic uitvlociscleienskappe, hidroliese lading en beweging, rietbedding-kenmerke en, in 'n sekere mate, omgewingstocstande. Vir moniteringsdocleindes is die rictbedding in drie dele verdeel wat van mekaar verskil het ten opsigte van helling, afmetings en samestelling van makrofietgemeenskappe. Om die uitwerking van vloeitempo, retensic, verskillende makrofietspesies en seisoensveranderinge op rietbeddingdoeltreffendheid te bepaal, is die verandering in uitvlociselsamestelling gemoniteer aan dic einde van elkeen van die rietbeddinggedeeltes. Dic ondersock is oor 'n periode van een jaar uitgevoer. Resultate het aangetoon dat rietbeddingbehandeling die gehalte van dic uitvlocisel verbeter het deur gesuspendeerde vastestowwe met $75 \%$ te verminder, ammoniak met $33 \%$, nitraat met $50 \%$, fosfaat met $12 \%$ en opgeloste organiese koolstol met $37 \%$.

Kortsluiting van die alvalwater het waarskynlik daartoe gelei dat fisiese en biologiese verwyderingsprosesse in die ecrste gedeelte van die rielbedding minder doeltrelfend was. Die konsentrasie van veranderlikes is hoofsaaklik verminder in die rietbeddinggedeclte met die poele, waar toestande ideaal was vir verhoogde assimilasie van nitraat en fosfaal deur alge, respirasie deur heterotrole bakteriee asook sedimentering en filtrering van gesuspendeerde vastestowwe. In hierdic gedeelte van die rietbedding het gesuspendecrde vastestowwe mel $69 \%$ verminder. nitraat met $47 \%$ en fosfaat met $18 \%$.

Ontleding van data wat seisoensgewys ingesamel is, hel getoon dat rictbeddingdoeltrellendheid algeneem het gedurende die winter wannecr lae temperature, verminderde sonbeligting en droë grondtoestande die tempo van fisiese en biologiese verwyderingsprosesse direk ol indirek beïnvloed.

Uit die ondersock het dit geblyk dat VS-rietbeddings aansientike polensiaal het as lackoste-, lactegnologie- en omgewingsvriendelike stelsels om voedingstofryke afvalwater te behandel. Omvangryke ekologiese studies sal egter meer spesilicke inligting genereer alangaande die komplekse wisselwerking tussen meganismes wat besoedelingstowwe verwyder en faktore wat dit beheer. Sulke inligting sal lei tot die ontwikkeling van betroubaarder ontwerpspesifikasies vir tockomstige rietbeddingstelsels.

\title{
Die evaluering van die Gewone Tarentaal (Numida meleagris) as aanduider van organochloriedbesoedeling
}

\author{
L. Lötter
}

(Verhandeling vir die M.Sc.graad; studieleier: prof. Henk Bouwman)

Departement Dierekunde, Potchefstroomse Universiteit vir Christelike Hoër Onderwys, Potchefstroom, 2520

Die studie het ten doel gehad om die Gewone Tarentaal as aanduider van organochloriedbesoedeling te evalueer. Organochloriedresiduvlakke en dic verspreiding daarvan in die bloed, lewer, niere, brein, hartspier en spierweefsels is bepaal.

Die voëls is op georganiseerde jagtogte versamel, monsters is geneem en die bloed en weelsels is gaschromatogralies geanaliseer. Korrelasiekoëffisiënte tussen dic bloed (niedestruktiewe monsternemingstegniek) en dic weelsels (destruktiewe monsternemingstegniek), die statisties betekenisvolle verskille tussen die studie-areas, en 'n risiko-analise vir die Gewone Tarentaal in die Noord-Wes Provinsie (NWP) en Westelike Kaapprovinsie (WKP) is bepaal.

Geen Gewone Tarentaal-eiers kon gedurende die studie gevind word nie. Die totale DDT-konsentrasic in dic eiers is dus geëkstrapoleer. Die totale DDT-cicrkonsentrasies is dus slegs 'n benadering van die werklike organochloriedkonsentrasies wat teenwoordig mag wees.

Die resultate dui aan dat die Gewone Tarentaal wel aan organochloriedinsektisiede in landbougebicde blootgestel word en dat die pestisiede in die liggaam akkumulecr. Die bloed, brein, nier en spierweefsels van die Gewone Tarentaal van die NWP het elk agt van die 14 geanaliseerde pestisiede bevat. Alhoewel die lewerweefsel slegs agt van die 14 pestisiede bevat het, het die lewer die hoogste gemiddelde organochloriedresiduvlakke gehad. Daarteenoor het dic bloedmonsters van die Gewone Tarentaal van die WKP 13 van die 14 geanaliseerde pestisiede beval. Alhoewel die lewerweefsel slegs agı van die 14 pestisiede bevat het, het die lewer die hoogste gemiddelde organochloriedresiduvlakke gehad.

Uit die resultate kan dus afgelei word dat die Gewone Tarentaal vanaf die WKP, indien dit me die organochloriedresiduvlakke van die Gewone Tarentaal vanaf die NWP, rool-en visvretende voëls vergelyk word, die hoogste gemiddelde pestisiedresiduvlakke toon.

Die organochloriedpestisiede tecnwoordig in die bloed en weefsels van die Gewone Tarentaal vanaf die NWP hou geen dirckte bedreiging vir die voëls in nie, terwyl dié voëls vanaf die WKP wel in gevaar verkeer. Dit word daaraan toegeskryf dat dic organochloriedvlakke in die weefsels van hierdic voëls, dic gerapporteerde residuvlakke (soos uit die literatuur verkry) van die roof-en visvretende voëls, oorskry het.

Die resultate verkry is dus strydig met die algemeen aanvaarde aanname dat rool- en visvretende voëls hoër pestisiedresidue as ander voëls het, en gevolglik sensitiewer vir organochloriedbesoedeling is as voëls wat hoofsaaklik saad-en insekvreters is.

Die resultate dui ook daarop dat die pestisiede 'n rol in die alname van Gewone Tarentaal-getalle mag specl, direk as gevolg van Ictale en subletale effekte en indirek as gevolg van die beperking op die beskikbaarheid van proteïenryke kos (insekte).

Die Gewone Tarentaal voldoen aan die karakteristieke van 'n aanduider en word as 'n geskikte terrestriële aanduider van omgewingsbesoedeling deur organochloriede beskou. 


\title{
Mineralogiese, petrografiese en geologiese kontrole op die assmelttemperatuur van steenkool van die New Clydesdale- steenkoolmyn, Witbank-steenkoolveld
}

\author{
S. Weeber \\ (Verhandeling vir die M.Sc.-graad; studieleier: prof. B. Cairncross; medestudieleier: dr: R.M.S. Falcon) \\ Departement Geologie, Randse Afrikaanse Universiteit, Posbus 524, Aucklandpark, 2006
}

Dic studiegebied vir hierdie projek is New Clydesdalesteenkoolmyn wat gelec is in dic Witbank-stecnkoolveld in dic noordelike deel van die Karookom, waar dic hoof steenkoolafsettings van Suid-Afrika voorkom. Die gunstigste assmelttemperaluur vir steenkool verkry in hierdie omgewing is ongevecr 1400 "C en hoër, alhoewel temperature bo 1300 "C ook aanvaarbaar is. In sekere steenkoollae is die assmelttemperature egter ver onder hierdie verlangde temperalure, wat tot probleme in die verbruikersindustric kan lei. Assmelttemperatuur - dic temperatuur waar die minerale in die steenkool begin versag, vloci en saamsmelt - is 'n belangrike aspek wat verband hou met die benutting van stcenkool, maar is 'n taamlik onbekende studieveld in Suid-Afrika.

Hierdie studie was daarop gemik om vas te stel watter faktore, mineralogies of anorganics-chemies, afwykings in steenkoolassmelttemperature in die No. 2-steenkoollaag beinnvlocd. Insig in hierdie probleem sal ' $n$ invloed uitoelen op die finale beoordeling van 'n steenkool vir benuttingdocleindes in die algemeen, en dic voorspelling van asafsetling in nuwe ketclinstallasies in besonder. Hierdic studic is in 'n mate baanbrekerswerk aangesien geen gedetailleerde ondersock voorheen onderneem of gepubliscer is nic.
Monsters is by vier lokaliteite op die New Clydesdalesteenkoolmyn geneem. Hicrdic lokaliteite is gekies op grond van vooral bestaande kennis van assmelttemperature verkry van maatskappy analitiese data. Die lokaliteite is dus verteenwoordigend van lac- en hoë-assmelttemperatuur-steenkool. Die ecrste twee lokaliteite was geleë in die oop mynbougebied waar die No. 2-laag aklief gemyn word. Die ander twee lokaliteite was ondergronds in gebiede waar mynbou nie meer plaasvind nie.

Konvensionele analise wat op die monsters uitgevoer is, sluit die volgende in: kortanalise, energicwaardes, persentasie swael en assmelttemperature. Verdere analises uitgevoer, behels die samestelling van dic as, X-straaldiffraksic, skandecelektronmiskroskopic en petrografiese studies.

Daar is gevind dat, alhoewel komplekse verhoudings bestaan tussen assmelttemperature en die verskillende geologiese en sleenkoolparameters, positiewe resultale verkry is. Hierdic resultale dui 'n moonllike verhouding aan tussen lae assmelttemperature en i) fynstecnkool, ii) 'n tocname in ystcrinhoud in die vorm van piriet en iii) die vorm waarin die piriet teenwoordig is, naamlik in nate. Hoë assmelttemperature neig om te korreleer met i) die afwesigheid van piriet of ii) piriet teenwoordig as framboïedes.

\section{Die implementering van 'n gerekenariseerde stelsel vir die bepaling van veldtoestande en monitering in 'n aantal sleutel beweidingsareas in die westelike grasveldbioom}

\author{
F.P. Jordaan \\ (Proefskrif vir die Ph.D.-graad; promotor: prof. J. Booysen) \\ Navorsingsinstituut vir Hervestigingsekologic, Potchefstroomse Universiteit vir Christelike Hoër Onderwys, \\ Potchel'stroom, 2520
}

\begin{abstract}
'n Fundamentele eienskap van enige ekosisteem is dal dit nic staties is of uit 'n vasgestelde samestelling bestaan nie. Alle ekosisteme is, in 'n mindere of meerdere matc, dinamies in tyd en ruimte. Moniteringstelsels vir die evaluering van sulke sisteme is dus van kardinale belang vir die daarstel van bestursmaatreëls en die evaluering van die impak daarvan om volgehoue ekstensiewe vecboerdery te verseker. Effektiewe moniteringsprogramme het hierdic evalueringsproses egter in die verlede gekortwick.

Spesiesamestellingsdata is binne ses redelik homogene boerderygebiede (RHB's) versamel. Hierdie RHB's is geselekteer omdat historiese data bestaan deur middel waarvan degradasicmodelle gekonstrueer kon word. Persele is sodanig geselekleer dat dit plantegroei in verskillende stadiums van degradasic verteenwoordig. Habitatinligting, wat chemies en lisies ontleed is, is ook by elke perseel versamel. Verder is bestursinligting
\end{abstract}

(lengte van beweidingsperiode, tipe dicr, rustydperk, ens.) van die persele van die bocre verkry.

Met hierdie studic is die ervaringskundigheid van die industrie dus gekwantiliseer en met behulp van mecrvoudige veranderlike statistick ontleed. Gelyklopend hiermee is 'n besluitnemingsondersteuningstelsel uit die resultate wat vanuit die omvangryke moniteringsopname in die westelike grasveldbioom verkry is, ontwikkel. Bestuursinligting hicruit gegenereer, het baic gunstig vergelyk met resultate uit dic ontleding van bestaande kundigheid. Die welenskaplike objektiwiteit, tyd en koste-ellektiwiteit en die uitskakcling van menslike partydigheid in die stelsel stel die cindgebruikers in staat om met tydige en kundige besluitnemingsinligting te bestuur, onalhanklik van persoonlike ervaring. Deur ekstrapolering van dic resultate kon sinvolle bestuursbeginsels ook geformuleer word vir kommunale gebiede, sonder onnodige duplisering van die studie in hicrdic gebiede. 


\section{Algspesies wat watersuiweringsprosesse by Balkfontein se watersuiweringsaanleg binnedring}

\section{R. Visser}

(Verhandeling vir die M.Sc.-graad; leier: prof. A.J.H. Pieterse)

Departement Plant- en Bodemwetenskappe, Potchefstroomse Universitcit vir Christelike Hoër Onderwys, Potchefstroom, 2520

In die huidige studie is aspekte van watersuiwering bestudecr. Aandag is veral aan die Vaalrivier gegee en die suiweringsaanleg by Balkfontein, naby Bothaville in dic Vrystaat is bestudecr.

By Balklontein word troebel, besoedelde goudveldwater vanaf die middel-Vaalrivier vir huishoudelike gebruik gesuiwer. Alge verstop sandfilters en verspreidingspype, verkort filterlopies, veroorsaak onsmakklike reuke en vermy sedimentasic tydens watersuiwering. Oor die algemeen dring algspesies die verskillende fases van watersuiwering binne en beland uiteindelik in dic drinkwater.

Die hoofdoel van die ondersock was om te bepaal wat die aard en omvang van alg- en algverwante probleme is en watler algtipes betrokke is, sowel as die verband tussen algselle in die rivierwater en algselle in die verskillende fases van watersuiwering. Algspesies van nege verskillende versamelingspunte in die aanleg is geïdentifiseer en konsentrasies is bepaal om sodoende die verwydering van algselle in verband te bring mel verskillende behandelingstoestande, soos byvoorbeeld doseringskonsentrasies. Verskillende flokkuleerders en ander chemikaliec̈ (byvoorbeeld ferrichloried, ferrisulfaat, kalk en chloor) het die algverwydering verskillend beïnvloed.

Verteenwoordigers van ses verskillende alggroepe was in die rivicrwater teenwoordig, asook in die water by die verskillende versamelpunte, naamlik blougroenalge, diatome, groenalge, kriptoliete, dinollagellate en euglenolietc. Differensiële verwydering van alge het by die verskillende prosesse wat gebruik is, voorgckom. 'n Verlaging in algbiomassa het by die verskillende fases van dic suiweringsproses voorgekom. Synechococcus cedrortum, Synechocystis sp. (blougrocnalge) en Monoraphidium arcualum, Monoraphidium circinale en Carteria globasa (groenalge) was die algspesies wat tydens die studieperiode tot in die drinkwater deurgedring het.

Die algspesies van die verskillende versamelpunte is in morlologiese groepe onderverdecl. Die eensellige groepe het die suiweringsproses meer gerecld deurdring as dic kolonic- en filamentgroepe. Die skyfvormige groep is in verhouding tol die ander groepe beter verwyder.

Dic suiweringsproses was nie suksesvol by die verwydering van alge tydens lae $\mathrm{FeCl}_{3}$-doseringstoestande en sonder voorchlorincring nic. ' $\mathrm{H}$ Hoë voor-kalk en $\mathrm{CO}_{2}$-dosering sonder ander chemikalicë, was nic suksesvol by die verwydering van alge nic. Die resultate van die studic dui aan dat verskillende alge of morfologiese groepe verskillende doseringstoestande nodig het om suksesvol tydens watersuiwering verwyder te word. 